\title{
KEMISKINAN NELAYAN: \\ Studi Kasus Penyebab Eksternal dan Upaya Revitalisasi Tradisi Pengentasannya di Kaliori, Rembang, Jawa Tengah
}

\author{
M. Alie Humaedi \\ Pusat Penelitian Kemasyarakatan dan Kebudayaan Lembaga Ilmu Pengetahuan Indonesia \\ Widya Graha Lantai 6/9 Jalan Gatot Subroto 10 Jakarta 12190 \\ Email: aliehumaedi@yahoo.com
}

Diterima 18 Januari 2012 - Disetujui 3 Desember 2012

\begin{abstract}
ABSTRAK
Kemiskinan masyarakat nelayan secara faktual terjadi di mana-mana. la tidak hanya disebabkan oleh faktor internal dalam mekanisme produksinya, tetapi juga oleh keadaan eksternal yang tercipta di lingkungannya. Tradisi dan kelembagaan tradisi tidak selalu dianggap baik dan mampu menjaga eksistensi kehidupan orang miskin. Bahkan, keduanya bisa menjerumuskan atau semakin membenamkan orang miskin pada kemiskinan absolut. Penelitian dilakukan dengan menggunakan metode etnografi. Penelitian etnografi masyarakat nelayan ini berupaya memberikan tawaran jalan keluar berdasarkan potensi dan karakter kebudayaan masyarakat dalam menghadapi kemiskinannya. Analisis data dilakukan secara deskriptif kualitatif. Hasil kajian adalah sebagai berikut. Buwoh dan bank titil di Kaliori Rembang Jawa Tengah telah menjadi bukti otentik bagaimana tradisi yang dikemas oleh para pencari rente lebih kejam dari jeratan utang bakul yang selama ini dituduh sebagai penyebab utama kemiskinan nelayan. Meskipun kondisi faktual kemiskinan itu tidak serta merta mendorong nelayan menjadi penganut konstruksi instrumental, peran pemerintah dalam menstimulasi tradisi dan kelembagaan tradisi yang mereduksi kemiskinan harus dipacu dalam bentuk kebijakan dan program.
\end{abstract}

Kata Kunci: penyebab eksternal, buwoh, bank titil, revitalisasi, tradisi, reduksi kemiskinan

\section{Abstract: The Fisher's Poverty: Case Study of External Causes and Tradition Revitalization effort to Poverty Allevation in the Kaliori of Rembang, Central Java. By: M. Alie Humaedi.}

Poverty in fishing communities occurs factually in everywhere. It is caused not only by internal factors in the mechanism of production, but also by external circumstances that are created in its environment. Tradition and traditional intitutions are not always considered good and able to maintain the existence of poor's life. In fact, they can plunge the poor people into absolute poverty. The research is conducted by using ethnographic method. This ethnograhic research of fishing communities attempted was to offer solution based on potention and character of public culture against their poverty. Data were analysed using qualitatove description method. Results of the study were as follows. Buwoh and Bank Titil in the Kaliori of Rembang, Central Java have become the authentic evidence of how traditions created by rente seekers are crueller than debt of bakul bondage that has been accused as the main cause of fisher's poverty. Although the factual condition of poverty does not necessarily encourage fishers to be adherents of the instrumental construction, the role of government in stimulating the tradition and tradition institutions that reduce poverty must be driven in the form of policies and programs.

Keywords: external causes of poverty, buwoh, bank titil, revitalization, traditions, and poverty reduction 


\section{PENDAHULUAN}

Persoalan keterbatasan modal, pengetahuan, keahlian, penggunaan teknologi alat tangkap dan overfishing seringkali dinyatakan sebagai penyebab kemiskinan atau rendahnya peningkatan kesejahteraan di masyarakat nelayan (Imron 2006; 2011). Selain itu, ada juga sinyalemen bahwa nelayan "dimiskinkan" sebagai akibat dari adanya monopoli distribusi hasil tangkapan yang banyak dikuasai oleh bakul atau depot. Untuk memuluskan penguasaan distribusi tangkapan itu, bakul mengikat nelayan jeragan (pemilik) perahu dengan utang yang tidak pernah dapat dilunasinya.

Sinyalemen di atas dibantah keras oleh M. Alie Humaedi dalam penelitiannya di Kaliori Rembang (2009-2011), bahwa melalui sistim bakul-langgan itulah yang sedikit banyak menawarkan kesejahteraan dan menjaga eksistensi kehidupan para nelayan miskin. Tidak hanya itu, sistim bakul-langgan yang dikenal pada kehidupan masyarakat jauh sebelumnya telah memungkinkan persebaran dan jeratan utang para nelayan miskin dari bank titil dengan rente tinggi itu dapat dikurangi. Bahkan, pasca tahun 1998, banyak langgan yang sebelumnya hanya menjadi pelaksana alat tangkapan kemudian menjadi juragan pemilik perahu setelah utangnya dibebaskan oleh para bakulnya, sebagai kompensasi dari hubungan patron-klien yang dilakukan sebelum itu. Sayangnya, setelah sistem bakul-langgan dengan mekanisme utang penuh sedikit demi sedikit dihilangkan dan diganti dengan sekadar hubungan "plakat jual beli" antara bakul dan langgan dengan nilai utang yang sangat kecil, telah membuat persebaran utang pada bank titil di masyarakat nelayan miskin semakin menjadi-jadi. Ini bukti bahwa, hubungan bakul-langgan tidak serta merta menjadi penyebab kemiskinan (Humaedi, 2010: 133-167).

Bila keterbatasan modal dan alat tangkapan, atau "bila terpaksa (penulis) memasukkan sistem hubungan bakullanggan" sebagai penyebab kemiskinan, maka unsur-unsur ini dapat dikelompokkan sebagai penyebab kemiskinan yang ada dan inheren di dalam mekanisme produksi masyarakat nelayan. Penyelesaian masalah atas aspek ini sebenarnya mudah dan praktis, yaitu dukungan dan penyediaan dana untuk merevitalisasi alat tangkapan dengan pinjaman lunak, pengembangan pengetahuan, peningkatan kemampuan dan teknologi alat tangkapan kepada nelayan. Tidak hanya itu, bila hubungan bakul-langgan dalam proses distribusi hasil tangkapan dianggap sebagai salah satu penyebab kemiskinan, maka ia harus dipotong dan diganti dengan sistim dan mekanisme distribusi modern seperti revitalisasi Tempat Pelelangan Ikan. Demikian juga usaha menghadirkan perusahaan kemasan dan distributor besar pemasaran ikan ke tempat-tempat nelayan penghasil produksi sebagaimana yang ditawarkan dalam butirbutir kawasan bahari terpadu misalnya bisa juga dilakukan oleh pemerintah (Satria, 2009; Adhuri, 2004).

Selain penyebab kemiskinan yang inheren dalam mekanisme produksi nelayan di atas, ada penyebab yang tidak kalah besar yang mampu memiskinkan masyarakat nelayan, baik dalam jangka pendek ataupun jangka panjang. Penyebab kemiskinan itu melekat pada situasi relasi sosial di masyarakat yang memengaruhi individu untuk memenuhi kewajiban sosialnya atas dasar kekerabatan, toleransi, dan roso. Salah satunya adalah buwoh (kondangan). Selain buwoh, salah satu penyebab kemiskinan nelayan adalah terjeratnya mereka pada mekanisme pemenuh kebutuhan uang tunai untuk kebutuhan pokok, kebutuhan produksi dan kewajiban sosialnya itu. Mekanisme ini adalah bank titil atau bank plecit atau koperasi yang mempraktikkan rente tinggi seperti bank titil. Kedua penyebab kemiskinan ini tidak mudah diatasi, terlebih hanya mengedepankan aspek struktural atau formalisme seperti kebijakan dan program pemerintah yang menawarkan pinjaman lunak ke masyarakat nelayan misalnya. Penyelesaian masalahnya perlu menggunakan strategi tertentu yang disesuaikan dengan kondisi kebiasaan masyarakat di mana dua praktik kebiasaan itu ada. 
Dengan demikian, bila keterbatasan modal, keahlian, teknologi dan "relasi sosial ekonomi bakul-langgan" dapat disebut sebagai penyebab kemiskinan internal atau inheren pada masyarakat nelayan, maka buwoh dan bank titil adalah penyebab kemiskinan yang diciptakan oleh suatu kondisi di masyarakat yang pengaruhnya kepada individu dan keluarga nelayan. Sederhananya, dapat disebut sebagai penyebab kemiskinan eksternal. Tulisan ini tidak lagi mau mengulang banyak tulisan yang telah menelisik pada penyebab kemiskinan internal, tetapi difokuskan pada penyebab kemiskinan eksternal. Karena itulah, fokus persoalan tulisan ini adalah bagaimana penyebab kemiskinan eksternal ini hadir di tengah masyarakat nelayan, dan bagaimana pemerintah dan pihak lain dapat menstimulasi nelayan untuk menghilangkan penyebab kemiskinan itu agar kesejahteraannya dapat meningkat. Harapannya, selain gambaran nyata tentang kemiskinan nelayan yang didasarkan pada aspek-aspek kultural, penelitian ini juga berusaha merumuskan dan menawarkan jalan keluar pengurangan kemiskinan berdasarkan tradisi dan kelembagaan tradisi yang telah dikenal juga oleh masyarakat nelayan.

\section{METODOLOGI}

\section{Waktu dan Lokasi Penelitian}

Tulisan ini didasari pada hasil penelitian lapangan selama tiga tahun (2009-2011) di desa-desa nelayan yang berada di Kecamatan Kaliori Rembang Jawa Tengah seperti Tunggulsari, Purworejo dan Pantiharjo. Untuk memperjelas karakter dan penyebab kemiskinannya, penelitian ini juga berusaha membandingkannya dengan beberapa desa pertanian. Dari tiga desa nelayan, Desa Tunggulsari menjadi lokasi utama penelitian. Desa ini berbatasan langsung dengan Kabupaten Pati yang penduduknya 90\% bermata pencarian nelayan tradisional. Sepuluh persen lain adalah petambak garam dan bandeng (UPK Kaliori 2010). $\mathrm{Di}$ Desa Tunggulsari inilah, 70\% masyarakatnya adalah nelayan miskin. Kemiskinannya tidak murni didasarkan pada penyebab internal dari aspek mata pencariannya, tetapi juga dipengaruhi oleh kondisi-kondisi di luar aspek mata pencariannya, seperti kebiasaan dan tradisi yang bersifat eksploitatif.

\section{Metode dan Teknik Pengumpulan Data}

Penelitian ini menggunakan metode etnografi, suatu metode yang menelisik lebih dalam tentang praktik-praktik kebudayaan masyarakat (Spreadly 1997). Teknik pengumpulan datanya dilakukan melalui wawancara mendalam, observasi, dan penceritaan kisah hidup, sebagai data primer. Selain teknik live in untuk menggali data faktual, peneliti juga memanfaatkan data sekunder berupa hasil diskusi terarah pada kelompok masyarakat, dokumen-dokumen pemerintah seperti jumlah kepemilikan sertifikat tanah dan dokumen implementasi PNPM Mandiri dan Program Keluarga Harapan. Dokumen ini penting sebagai bahan pengurai indikator kemiskinan yang bersifat formal dengan kenyataan yang ada dan menjadi indikator subyektif kemiskinan yang ada dan terjadi di masyarakat.

\section{Analisis Data}

Setelah data primer yang berasal dari lapangan didapat, data itu kemudian dianalisis dan dituliskan secara deskriptif. Beberapa hal yang berhubungan dengan masalah penyebab kemiskinan, sebagaimana menjadi tema penelitian dianalisis secara eksplanatif dan interpretatif. Tujuannya untuk menghasilkan penjelasan dan perbandingan antara penyebab kemiskinan dan kapasitas masyarakat nelayan dalam mengentaskan kemiskinan.

\section{HASIL DAN PEMBAHASAN}

\section{Kisah Hidup Keluarga Nelayan Miskin: Kasus} Pak Jimin

Terasa aneh bila meneliti kemiskinan tetapi tidak menyodorkan kisah hidup dari seorang dan keluarganya yang diindikasikan masuk ke dalam kriteria miskin, atau dalam bahasa setempatnya seringkali disebut sekeng. 
Kisah hidup dibutuhkan untuk merunut satu narasi mengenai kemiskinan yang turun-temurun. Bila pak Jumari, ketua UPK Kaliori, dengan mendasarkan pendapatnya berdasarkan standar operasional PNPM Mandiri, saat wawancara tanggal $11 \mathrm{Juli}$ 2010 telah membagi orang miskin itu pada dua jenis; miskin absolut, di mana ia tidak ada upaya sama sekali untuk meningkatkan kesejahteraan, karena ketiadaan alat produksi; dan juga miskin produktif; di mana seseorang dapat dikelompokkan miskin tetapi ia memiliki kemampuan untuk bekerja, baik kepada orang lain ataupun bekerja mandiri berdasarkan alat produksi yang dimilikinya, maka semua itu seharusnya dipetakan dalam sebuah kisah hidup yang jelas dan runtut. Di bawah ini akan dikisahkan perjalanan hidup seorang nelayan miskin yang berasal dari Desa Tunggulsari, Kaliori Rembang.

Namanya Jimin, nama dari orangtuanya yang berasal dari Pecangaan Pati, dan pindah ke Tunggulsari karena ikut istri. Seorang nelayan miskin dengan penampilan fisik yang layu dan teramat sederhana, padahal usianya baru 48 tahun saja. la dan keluarganya: 7 orang anak; yang sulung dan bungsu perempuan dan empat anak lainnya adalah laki-laki; yang satunya ada di Ujung Pangkah Gresik, ditambah seorang yang sudah berusia lanjut, ibu pak Jimin itu. la ikut tinggal di rumah di atas tanah pinjaman yang sangat sederhana. Sejak masih kecil, terlebih saat bapaknya meninggal, sang ibu tinggal secara berpindah dari satu tetangga ke tetangga lain. Anak-anak pun dititipkan di sana-sini, bekerja apa saja untuk menghidupi dirinya.

Semua anak menjadi terlantar, karena ketidakmampuan sang ibu menafkahi anaknya setelah ditinggal suami. Rumah hasil warisan pun terpaksa dijual untuk biaya pengurusan jenazah, membayar utang pada bank titil ataupun utang pada tetangganya, dan sebagian untuk biaya pengasuhan anak yang saat itu masih kecil. Saat itu pula anak-anaknya telah dititipkan ke tetangga, termasuk Jimin. la dibesarkan oleh banyak orang dan bekerja sejak usianya masih kecil; nyait (membersihkan perahu), alang-alang (meminta ikan), sampai ikut perahu atau pendego (anak buah kapal), ketika beranjak besar. la pun nunut urip (ikut menumpang hidup) ke orang lain.

Untungnya tiga anak Jimin sekarang sudah pisah, walaupun bekerja seadanya, sehingga salah satu adik mereka yang sekarang kelas 6 SD bisa ikut didukung bersama-sama. Kalau tidak sulit rasanya, walaupun ia tahu bahwa perjalanan manusia itu seperti jeriji tangan niki (jari tangan ini); ada jempol (di bawah), penudu (naik), tengah (puncak kejayaan) sampai menjadi jentik (kelingking) kembali yang turun pamornya. Inilah takdir. Walaupun semua proses itu harus dijalaninya dengan sabar, tetapi Jimin tidak lagi bisa berbuat banyak untuk sekadar nempur (membeli beras). Pak Jimin menyatakan hidupnya terasa aneh, mengapa kesengsaraan itu tidak pernah lepas dari keluarganya, bahkan ditambahi dengan ibu yang sudah renta itu. Jangan-jangan, menurutnya, anak saya pun nanti akan menjadi miskin seperti dirinya.

Rumah yang dihuni ini tidak memiliki akses air PAM ataupun sumur. Sehingga air yang digunakan untuk memenuhi kebutuhan berasal dari air hujan, tadahan dari talang tetangga depan rumahnya atau mengambilnya di embungan (kolam besar) milik masyarakat. Dapur yang sangat becek, karena tidak ada aliran air ke selokan. Semuanya bercampur dengan dapur yang baunya juga sudah tidak sedap lagi alias jorok. Panci dan piring kotor berserakan di atas tanah yang becek itu. Semuanya tidak tertata rapi, ruangan dapur dan jeding ini berada di samping rumah beratap genting keripik dan semuanya berdinding gedek.

Belanja beras (nempur) dan solar harian pun sudah sulit untuk diperoleh, apalagi ketika harga BBM di tahun 2008 meningkat tajam, dan jaring tangkapnya pun banyak yang rusak. Setiap hari, ia hanya nempur $1 \mathrm{~kg}$ untuk makan (bekal dan siang), ibu tua, dan Umiyatun sendiri. Kurang atau tidaknya harus dipaskan; rokok pun dibeli untuk dua hari sekali. la menghematnya dengan cara merokok sehabis makan saja, dan solar bisa habis Rp 30-40 ribu setiap harinya. Kebutuhan 
pokok ini belum juga ditambah jika ada ulem (undangan) untuk buwoh (hajatan) yang wajib dihadiri dengan nilai uang yang sudah dianggap umum masyarakat.

Kalau tidak buwoh, keluarganya akan disisihkan dan tidak dibantu kalau terjadi apaapa. Padahal keluarganya sendiri memang membutuhkan bantuan anggota masyarakat lain, khususnya ketika salah satu anggota keluarganya ada yang sakit atau sekadar untuk biaya SPPnya Umiyatun. Bila mereka tidak melakukan buwoh, anggota masyarakat lain pun enggan membantunya, karena keluarga Jimin dianggap tidak roso. Sayangnya, pemenuhan kebutuhan pokok dan keperluan buwoh itu tidak jarang harus didapatinya dari bank titil. Kebutuhan uang pun semakin bertambah, karena harus membayar cicilan bank titil yang juga tidak pernah selesai kapan habisnya. Untuk itu, ia harus menyisihkan uang Rp. 10.000 per satu kali cicilan. Padahal utangnya hanya Rp. 300.000 , tetapi bayarnya sampai Rp. 700.000, karena telat mencicil. la sering dikenakan bunga tambahan atas pinjaman pokok. Bahkan bunga itu kemudian menjadi pokok pinjaman. Padahal belum tentu saat melaut dirinya dapat rajungan atau alat payangnya menjerat $1 \mathrm{~kg}$ udang yang hasilnya bisa membayar cicilan itu.

Semuanya harus berhemat, dan setiap harinya ia tidak punya uang cadangan apapun. Bila ada kebutuhan mendadak, maka ia harus meminjam kepada anak yang juga kekurangan, di mana untuk mengembalikannya, ia tidak jarang meminjam kembali ke bank titil yang lain sebanyak Rp. 100.000, dengan cicilan Rp. 5.000 selama 40 hari (Rp. 200.000 atau bunganya mencapai $100 \%$ ). Bank titil mudah didapat, karena umumnya orang sini juga meminjam dari mereka. Kalau ia butuh, ia tinggal pesan ke tetangga, bila ada tukang titil agar mampir ke tempatnya. Ketika bank titil datang, mereka akan meminjam KTP atau KK asli terlebih dahulu untuk diproses atau difotokopi. Sehari kemudian, mereka datang menyerahkan uang beserta KTP atau KK yang dipinjamnya kemarin.
Sehari kemudian mereka sudah mencicil kembali uang pinjamannya. Bila tidak ada, maka dalam beberapa kali tunggakan, rupanya akan dibungakan kembali, dan demikian seterusnya. Jimin sendiri tidak mau meminta-minta uang atau barang kepada anaknya karena nanti dituduh masyarakat "kok beli isin, paringparing putra-putri nipun" (tidak memberi anak, malah minta-minta, seharusnya malu kalau jadi orangtua). Paling banter, Jimin sekadar meminjam yang segera dikembalikan ke anak pada tempo waktu yang ditentukan. la sendiri sangat jarang meminjam uang kepada tetangga, karena tetangga seringkali menuduhnya orang yang tidak jujur, kalau uang pinjaman itu sering digunakan untuk beli jajan makanan dan rokok. Umiyatun pernah diminta pak Yakup, tokoh masyarakat, untuk disekolahkan, tetapi tidak diperbolehkan. Pak Jimin sendiri meminta Umiyatun sehabis SD itu langsung bekerja di warung kakaknya. Sebuah proses yang tidak menawarkan perubahan akhirnya.

\section{Penyebab Kemiskinan Eksternal}

Pak Jimin, adalah satu dari 78 kepala keluarga nelayan miskin yang berada di Desa Tunggulsari Kaliori Rembang. Dalam catatan pinjaman bank titil (yang sering mengatasnamakan LKM) "Sri Rejeki" di tahun 2010, hampir keseluruhan kepala keluarga (atas nama istri) memiliki utang kepada bank titilnya. Dalam monografi desa (2010) yang mencakup juga wilayah pertanian disebutkan jumlah keseluruhan penduduknya 1217 jiwa yang terdiri dari 279 KK. Artinya, ada sekitar $26 \%$ penduduknya yang dikategorikan miskin atau sekeng. Keadaan seperti ini hampir terjadi di semua wilayah nelayan, bahkan angkanya ada yang melampaui $35 \%$, seperti di salah satu desa dari Tridesa di Kabupaten Demak (Mubyarto 1984). Dari kisah hidup di atas, sedikitnya ada dua penyebab kemiskinan eksternal pada masyarakat nelayan, yaitu buwoh dan bank titil.

\section{Buwoh: Pemborosan dan Perusakan Rencana Keuangan}

Salah satu perilaku dan tradisi yang dilahirkan dari perasaan dan tuntutan kewajiban 
keluarga dan kewajiban sosial masyarakat nelayan adalah buwoh. Buwoh, menurut ibu Sri Hastuti di Tunggulsari berasal dari kata uwoh, buah. Buwoh berarti membuah atau mendapatkan hasil buah. Kalau ia dimengerti sebagai buah, pertanyaannya apa yang ditanam sehingga menghasilkan buah itu? Si ibu menjawab bahwa mereka sedang nandur wiwitan yatra (menanam pohon uang). Pohon uang itu diilustrasikannya sebagai sesuatu yang mengakar dan mengikat sifatnya ke dalam elemen tanah. Di lain desa, tradisi buwoh banyak nama, seperti demen, weweh, kondangan, nyumbang, dan ngamplop.

Bagi masyarakat Tunggulsari, buwoh adalah satu tradisi memberikan sumbangan ke orang lain yang sedang mengadakan hajatan yang berhubungan dengan sesuatu yang membahagiakan, seperti pernikahan, khitanan, dan mendirikan rumah. Selain keluarga dekat dan jauh, tetangga dekat dan luar desa pun diundang. Dalam pelaksanaannya hampir tidak ada perbedaan jenis materi yang diberikan. la bisa berbentuk uang dan barang, baik dalam pengertian sendiri ataupun gabungan keduanya. Barang itu bisa terdiri dari beras, gula, teh, tepung, dan pakaian. Perbedaannya terletak pada jumlah uang dan barang yang diberikan. Perbedaan ini tidak hanya terjadi bila dibandingkan dengan daerah lain, sesama desa di Kecamatan Kaliori saja terjadi perbedaan yang signifikan. Anehnya wilayah pesisir seperti Tunggulsari, jumlah buwohnya lebih besar dari desa petani. Hal ini disebabkan oleh biaya hajatan di desa pesisir dianggap lebih besar dari desa pertanian. Pada 2010, di Desa Tunggulsari, ada kesepakatan umum tidak tertulis bahwa uang buwoh untuk pernikahan sebesar Rp. 35.000; untuk khitanan Rp. 20.000, dan syukuran mendirikan rumah rata-rata Rp. 10.000. Jumlah uang ini bisa diganti dalam bentuk barang: $2 \mathrm{~kg}$ beras, gula $2 \mathrm{~kg}, 1$ bungkus teh, dan $1 \mathrm{~kg}$ tepung untuk diantarkan dalam acara pernikahan; atau beras $2 \mathrm{~kg}$ dan $1 \mathrm{~kg}$ gula untuk khitanan; dan $2 \mathrm{~kg}$ beras untuk syukuran rumah.

Bagi masyarakat nelayan, yang rata-rata tidak memiliki sawah atau tanah yang bisa digunakan untuk lahan produksi, sepenuhnya tergantung pada hasil laut untuk ikut urun buwoh. Bila musim rejeh atau banyak ikan, buwoh tidak akan membawa banyak persoalan, karena hasil laut tiga bulan bisa menjamin kehidupan mereka dalam ambang batas kebutuhan minimal selama satu tahun. Dengan perhitungan harga pasar pada tahun 2010, kebutuhan minimal nonbiaya produksi kerja harian keluarga nelayan di Tunggulsari sebesar Rp. 25.000. Kebutuhan minimal itu menyangkut beras $2 \mathrm{~kg}$ (Rp. 12.000), lauk pauk selain ikan seperti tempe dan tahu (Rp. 3.000), sayuran (Rp. 2.000), bahan bakar (Rp. 3.000), dan Rp. 2.500 adalah biaya sekolah. Setiap bulan keluarga nelayan membutuhkan sedikitnya Rp. 675.000 untuk kebutuhan minimal, dan Rp. 1.000.000 untuk modal produksi. Setiap melaut sedikitnya membutuhkan 5 liter solar (Rp. 27.500)1.

Sulit rasanya untuk memenuhi kebutuhan minimal dan modal produksi itu pada musim leyep atau pailah, karena hasil laut sangat sedikit. Tidak jarang di musim ini mereka hanya mendapatkan 2 - 5 ekor rajungan ditambah beberapa ekor ikan saja; nilainya pun tidak lebih dari Rp. 20.000 sampai Rp. 25.000 saja. Untuk menyiasatinya, mereka mengurangi penggunaan solar dengan cara menaikkan layar, seperti dikenal dan dipraktikkan masyarakat nelayan dahulu. Mereka juga membatasi diri untuk tidak terlalu jauh dalam penangkapan ikan dan rajungannya. Karena semakin jauh, semakin besar modalnya, tetapi semakin dekat jaraknya dengan daratan, semakin sedikit hasil tangkapannya.

Karena itu untuk memenuhi kebutuhan minimal pada musim leyepan mereka harus berutang. Dahulu utang itu bisa diajukan kepada para bakul atau depot, sekarang bakul

\footnotetext{
${ }^{1}$ Bandingkan angka pengeluaran ini dengan 14 indikasi kemiskinan BPS yang salahsatunya menyebutkan bahwa sedikitnya penghasilan kepala keluarga harus 425.000. Padahal kebutuhan minimal saja telah mencapai angka Rp675.000. Bila kebutuhan minimal ini dijadikan indikasi kemiskinan dalam versi lokal, maka jumlah Rumah Tangga Miskin yang awalnya hanya $26 \%$ bisa langsung mencapai angka $40 \%$ (Kleden-Probonegoro 2011)
} 
kebanyakan tidak lagi mengutangi langgannya, kecuali utang pokok yang tujuannya sebagai alat ikat saja. Mereka pun akhirnya banyak berutang kepada bankplecit atau bank titil, termasuk juga kepada lembaga keuangan mikro yang menjamur di masyarakat pedesaan pesisir itu. Ada juga dengan cara menjual barang rumah tangga, seperti perhiasan emas, televisi, radio, tape recorder, piring, sendok, dan lemari yang dibeli sewaktu musim rejeh (musim banyak ikan). Anehnya, walaupun dalam kondisi di mana untuk kebutuhan minimal saja sulit diperoleh, hampir semua undangan buwoh akan selalu dihadiri. Apalagi bila keluarga yang diundang akan mengadakan hajatan dalam waktu dekat atau ketika pengundang pernah datang buwoh pada waktu keluarga yang diundang itu melakukan hajatan sebelumnya. Untuk urusan yang satu ini, mereka pun berani meminjam uang kepada keluarga, tetangga, dan bank plecit. Hampir dapat dikatakan bahwa $76 \mathrm{KK}$ itu pernah terlibat aktif atau sedang utang kepada bank titil atau bank plecit sebagai akibat dari pemenuhan kebutuhan buwoh, khususnya pada musim-musim hajatan (maulid, syawal dan rajab) yang tepat bersamaan waktunya dengan musim leyep pada sistem waktu penangkapan ikan yang dikenal masyarakat nelayan. Hal ini dinyatakan oleh para penagih bank titil dari Eka Jaya dan Sri Rejeki pada wawancara di bulan Juli 2010. Bahkan sebagian besar dari 76 KK itu terlibat utang lebih dari satu lembaga bank titil. Para pelakunya kebanyakan adalah nelayan-nelayan miskin yang menjadi pendego atau nelayan yang memiliki daya tangkap sederhana.

Namun demikian, mereka dengan penuh sadar, yakin dan percaya diri akan dapat mengembalikan utangnya pada musim rejeh mendatang. Saat musim itu tiba, hasilnya digunakan untuk membayar utang ke keluarganya, tetangganya, dan beberapa bank plecit. Namun kenyataannya, tidak semua utang pada bank titil pada satu musim panen (rejeh) itu bisa dilunasi. Ada diantaranya yang masih tertunggak, bahkan telah menjadi pokok utang baru dari pinjaman dengan sistem rente itu. Sementara utang kepada program pemerintah seperti Simpan Pinjam
Ekonomi Perempuan PNPM Mandiri tidak akan ditutup, kecuali dialirkan begitu saja sampai jatuh tempo. Bila seandainya mereka sedikit atau sama sekali tidak memiliki utang pada musim leyepan, mereka akan membelikan beberapa gram emas, perabotan rumah tangga, bahkan kendaraan bermotor. Barang ini akan dijual kembali pada saat kebutuhan mendesak, termasuk saat undangan buwoh terlalu banyak. Sistem menabung dalam bentuk barang, khususnya emas sebenarnya lebih efektif, dibandingkan dengan cara berpikir yang dipegang oleh anggota masyarakat bahwa buwoh juga adalah sistem atau mekanisme kultural yang bertujuan menabung sebagian hasil perolehan pada satu musim panen untuk masa-masa yang akan datang. Pola pikir tentang buwoh ini juga diikuti dengan perspektif bahwa berutang kepada bank titil seolah diartikan sebagai ikhtiar menabung. Bila tanpa berutang kepada bank titil sekalipun untuk keperluan buwoh akan dianggap bahwa mereka tidak bisa menabung. Perspektif ini sangat berbahaya, karena bisa menyuburkan tradisi utang terus-menerus di masyarakat Desa Tunggulsari Kaliori.

\section{Praktik Rente Bank Titil}

Dalam konteks pedesaan Kaliori, bank titil, suatu lembaga keuangan mikro,dikenal juga dengan plecit dan minggonadalah salah satu alat (kelembagaan) ekonomi yang mampu mengatasi persoalan pemenuhan kebutuhan masyarakat. Istilah bank titil merujuk pada satu sistem utang-piutang yang menggunakan mekanisme pembayaran cicilan berbunga (rente). Rentang waktu pembayaran disepakati antara pihak pengutang dengan pemberi utang atau kelembagaan kredit. Ketetapan waktu bisa diatur berdasar hari atau minggu yang kesepakatannya diberi plakat dengan kupon yang di-titil. Titel atau tetel merujuk istilah dari kegiatan menetel kupon. Bila dikatakerjakan, menetel (memecah) merujuk pada pengertian memecah sejumlah uang besar dalam jumlah lebih kecil. Pengecilan jumlah itu adalah cara mudah mencicil utang yang dimiliki seseorang. Dengan angka yang telah ditetapkan, pihak si pemberi utang atau lembaga keuangan akan 
mencari untung. Kupon jatah pengembalian si pengutang harus habis sesuai hitungan pinjamannya.

Ada beberapa jenis harga kupon, dari per seribuan sampai limapuluh ribuan. Kupon per 1000an digunakan untuk pinjaman Rp. 20.000an yang harus dibayar dengan kupon berjumlah 25 buah. Kupon Rp. 5.000 digunakan untuk pinjaman Rp. 100.000an yang wajib diselesaikan sebanyak 25 kupon. Dalam hitungan titel, 20 kupon dibebankan untuk pengembalian utang pokok, dan 5 kupon lain dianggap biaya administrasi dan biaya keliling agen titel-nya. Selisih dengan utang pokok biasanya adalah lima kupon. Selisih inilah yang memberatkan. Perhitungan secara seksama dari utang Rp. 100.000 yang dibayar sebanyak 25 kupon per lima ribuan, bunganya mencapai angka $50 \%$. Hitung saja 25 x Rp. 5.000 adalah Rp. 125.000 dan dibayar selama 25 hari. Karena belum memiliki limit waktu satu bulan, bunga dihitung dalam satuan hari. Bunga per seratus ribu berarti per seribu per hari. Angka ini terus bertambah bila si pengutang belum dapat menghabiskan 25 kupon dalam tenggat waktu yang ada.

Keringanan pengembalian hanya diberikan sebanyak 2 kali saja, selebihnya dikenakan bunga berbunga. Bila si pengutang tidak bisa membayar lima kupon dalam lima hari, maka utang pokoknya ditambahkan dengan kelipatan dua kali. Jumlah utang Rp. 25.000 bisa menjadi Rp. 35.000 , dan seterusnya. Bila kupon itu belum habis setengahnya dari 25 hari, maka utangnya akan bertambah sebesar 15 kupon. Bila utang itu sudah dua kali lipat dengan utang pokok, maka bunga dihentikan, dan si pengutang wajib menyerahkan apapun yang dimiliki dengan paksaan. Karena itu, bisa jadi televisi, tape, peralatan dapur, dan lainnya akan dibawa pergi oleh si pemberi utang. Barang yang dibawa minimalnya mempunyai harga Rp. 250 ribu, kalau tidak ia pun bisa menyita apapun yang ada.

Pak Jimin, ayahnya Umiyatun di Tunggulsari, televisi rumahnya pernah dibawa pergi oleh si pemberi utang (bank titel Eka Jaya), karena awalnya ia hanya meminjam
Rp. 50.000 untuk keperluan buwoh dan beli rokok. Semua orang sini tahu bagaimana tukang tetel kupon itu membawa televisi dari rumahnya meskipun si Umiyatun menjerit dan menangis kencang agar televisi itu tidak dibawa. Anehnya, setelah peristiwa itu, si tukang tetel kupon itu masih saja mendekati keluarga Jimin dan menawarinya untuk berutang. Dengan iming-iming mudah dapat uang, cepat, dan hanya mensyaratkan fotokopi KTP saja, ia pun kerap menghampiri rumah Jimin. Dengan pura-pura bisa membantu sekolah Umiyatun, karena pihaknya menyediakan beasiswa bagi si pengutang. Jimin pun akhirnya kembali berutang Rp. 100.000 kepada bank titel tersebut. Ia dikenakan kewajiban untuk menghabiskan 25 kupon per seribu. Ketika Jimin menagih soal beasiswa si Umiyatun, tukang titel itu menyatakan bahwa beasiswanya sudah terlambat karena diberikan pada awal tahun ajaran baru. Pada peminjaman uang kedua itu, Jimin bisa mengembalikannya tepat waktu karena kondisi lautnya sedang membuahkan banyak hasil.

Menurutnya, kalau kondisi laut sedang bagus, daripada ia bayar cicil 25 hari, dalam dua hari saja ia dapat menyelesaikan pinjaman plecit itu. Kemampuan membayar tunai dua hari itu tidak akan menjadi pilihan. Ia lebih memilih menggunakan uang sisa dari melaut sebagai sarana membeli televisi baru sebagai pengganti televisi yang sebelumnya pernah disita. Untuk kekurangan memenuhi itu, ia pun kembali berutang kepada bank plecit kedua, yang disebut tukang titel-nya adalah pak Herman (LKM Trinasih).

la pun berutang Rp. 200.000 dengan kupon sebanyak 25 kupon per sepuluhan ribu dalam dua puluh lima hari. Bila ditambahkan dengan utang awal pada bank plecit pertama, setiap harinya ia harus membayar kupon sebesar Rp. 15.000. Utang baru ini dilakukan orang bila kondisi melautnya dianggap sedang baik. Anehnya, kondisi baik atau musim rejeh, malah berusaha untuk tambah berutang, sebaliknya kondisi susah atau leyep, mereka sangat berhati-hati untuk berutang. Dengan prinsip apapun kebutuhan atas pembayaran utang pada musim rejeh dapat dilakukan 
berapapun besarnya. Mereka bisa menyisihkan maksimal Rp.50.000 per hari untuk pembayaran utang. Musim rejeh berlangsung sedikitnya satu bulan, dan maksimalnya dua bulan. Walaupun sekali lagi kondisi seperti ini sekarang tidak lagi begitu jelas. Sedangkan pada musim leyepan, mereka hanya bisa mencukupi kebutuhan hidup maksimal Rp. 15.000 per hari. Bila ada biaya tambahan hidup, biaya itu ditambah sebagai beban yang berat. Termasuk biaya anak sekolah yang menggunakan transportasi umum. Bahkan paling sering dijumpai adalah peminjaman uang kepada bank titil dengan alasan untuk keperluan buwoh kepada tetangganya. Alasan ini dinyatakan dengan pertimbangan solidaritas dan roso seperti yang dialami juga oleh pak Jimin saat meminjam ke bank titil pada cerita di atas. Fenomena seperti ini sangat banyak dijumpai di masyarakat pedesaan Kaliori.

Nelayan miskin di Tunggulsari yang sedikitnya berjumlah 76 KK itu rata-rata pernah dan sedang terlibat dengan bank titel. Dari 76 KK itu, mereka akan terlibat kembali pada pengutangannya, setelah utang sebelumnya lunas atau dianggap lunas dengan sistem penyitaan barang yang dilakukan para penetel kupon itu. Bahkan utangannya bisa berasal lebih dari satu bank titel. Satu utangan di bank "Eka Jaya", satu lagi di "Trinasih" atau satu lainnya di bank titel atas nama perseorangan, misalnya milik pak Udin dari Mojorembun Kaliori. Seluruh kemampuan atau produksi ekonominya hanya ditujukan untuk membayari kupon yang telah ditetapkan itu. Sistem dan mekanisme utang ke bank titil untuk keperluan dan alasan apapun, termasuk untuk buwoh menjadi persoalan utama yang dihadapi masyarakat nelayan miskin di pedesaan. Di satu sisi mereka membutuhkan uang untuk membeli beras, lauk pauk, uang sekolah, dan buwoh tetapi di sisi lain mereka semakin diikat oleh utang berbunga tinggi.

Bank titel tetaplah bagian dari "semacam kelembagaan tradisi" di masyarakat yang bisa menjadi penyangga sementara keluarga saat mengalami keterbatasan ekonomi atau keadaan ekonomi yang "megap-megap (subsisten)".
Meskipun, kalau tidak bisa membayar, perabotan akan dibawa agen bank titel. Kalau jumlahnya besar dan membengkak, rumah dan tanah menjadi jaminan. Persoalan ini adalah pilihan berat dari berkecambahnya satu institusi keuangan yang dahulunya dikembangkan swasta dan pemerintah dengan model bank pasar atau bank rakyat itu; walaupun ada rekayasa model yang diambil dari masyarakat melalui sistem arisan dan ijon. Ketika model bank titil ini diformalkan menjadi lembaga keuangan mikro, dampaknya tidak lagi menjadi penyangga utama masyarakat miskin. Meskipun bank komersial telah menawarkan bunga sedikit rendah dan tidak menggunakan mekanisme bunga berlipat, lembaga keuangan mikro yang mempraktikkan bank titel baik milik perseorangan atau perserikatan yang memakai nama koperasi masih memiliki pasarnya sendiri.

Bila kondisi di atas dibiarkan terus oleh pemerintah, maka sebagaimana yang terlihat pada kasus 76 keluarga di Desa Tunggulsari Kaliori para nelayan akan tetap berada pada garis kemiskinannya. Hal ini terlihat pada dampak jangka pendek dan jangka panjang ketika mereka berutang kepada bank titil. Dampak jangka pendek adalah hilangnya konsentrasi dan kemampuan keluarga dalam pembiayaan kebutuhan terpokok hariannya. Mereka hanya akan berkonsentrasi pada penyelesaian utang yang bisa saja terus menerus bertambah. Sementara dampak jangka panjang adalah hilangnya kesejahteraan masyarakat nelayan yang menyebabkan munculnya ketidakpercayaan kepada anggota masyarakat lain dan kepada negara sebagai pelindung hak-hak warga negara. Bila dua hal terakhir ini telah muncul di dalam masyarakat, maka konflik antar anggota masyarakat dan kepada negara yang bersifat laten dan nyata sangat mungkin terjadi. Dengan demikian, persoalan tawuran para pemuda dan pendego nelayan, pengerusakan kapal-kapal tangkapan jenis lain, kasus perceraian yang tinggi, dan pencurian harus dilihat dalam hubungannya dengan tingkat kesejahteraan nelayan dan keterjeratan mereka dengan sistim utang bank titil ini. 


\section{Revitalisasi Tradisi Reduksi Kemiskinan: Ikhtiar Mengatasinya}

Fenomena bank titil di masyarakat nelayan akan selalu dipertanyakan kehadirannya, apakah penyebabnya semata berada pada aras struktural, di mana alasan akses perkreditan seperti ketiadaan agunan, proses cepat, mekanisme mudah, dan tidak repot menjadi apologi yang selalu dikedepankan. Atau jangan-jangan terdapat alasan lebih berbahaya lagi, yaitu serangkaian alasan kultural yang menyebabkan masyarakat terus bergantung dan tidak mau menjauhi sistem utang rente ini? Asumsi ini sama halnya dengan alasan kultural yang terdapat pada praktik buwoh sebagai bagian dari kewajiban sosialnya itu.

Bahkan, koperasi yang awal berdirinya selalu mencerminkan akar kultur masyarakat, seperti musyawarah dan mufakat, mekanisme dan pembagian hasil usaha, digunakan namanya dan disalahkaprahkan sebagai bagian dari suatu proses penghisapan modal yang terdapat di masyarakat. Modifikasi koperasi yang salah kaprah ini tentu berasal dari suatu pertemuan kepentingan dari "pemilik pribadi koperasi" dan "masyarakat pengutang". Masalahnya adalah bagaimana pertemuan kepentingan itu bisa hadir dalam bentuk koperasi yang mempraktikkan bank titel, bila tidak diiringi semacam kemauan dan "pengelolaan kebudayaan" atau tepatnya siasat kebudayaan yang dianggap baik oleh pemilik walaupun itu dirasakan "salah" oleh masyarakat umum.

Bisa dikatakan, "pengelolaan kebudayaan" yang ada dilakukan untuk kepentingan diri atau bersifat sepihak saja, tidak berada pada satu kepentingan bersama komunitas. Jadi, pengelolaan kebudayaan, yang baik atau yang salah (secara struktural dan kultural), bisa dilakukan oleh siapa pun, termasuk pelaku pasar kapital (bank titel dan rentenir) yang memodifikasi koperasi sebagai alat hisap sumber daya masyarakat. Artinya, bank titil dan buwoh sekalipun adalah hasil "pengelolaan kebudayaan" atau tepatnya "siasat eksistensi" yang bersifat sepihak, dari para pemburu rente dan pencari keuntungan selisih harga.

Bila keadaannya seperti ini, maka penyebab kemiskinan masyarakat nelayan yang sifatnya eksternal sesungguhnya dapat diatasi dengan "pengelolaan kebudayaan" yang sifatnya komunitas dan massif. Artinya, kemauan dan kepentingan bersama yang harus dikedepankan untuk sama-sama menopang dan menjaga eksistensi kehidupan warganya, khususnya bagi mereka yang dikategorikan miskin atau sekeng. Kelembagaan tradisi yang betul-betul memiliki fungsi mereduksi kemiskinan atau minimalnya mampu menjaga eksistensi harus didorong dan direvitalisasi sebagai kekuatan bersama untuk mengatasi keterbatasan dan ketidakmampuan aspek kehidupan masyarakat.

\section{Tradisi Reduksi Kemiskinan Nelayan}

Masyarakat nelayan Tunggulsari sebenarnya telah mengenal beberapa tradisi yang memiliki potensi menjaga kehidupan dan mereduksi kemiskinan. Sedikitnya tercatat empat tradisi yang memiliki peran itu.

Pertama, koloran, tradisi memanfaatkan tanah timbul di pinggiran pantai untuk kepentingan lahan produksi tambak dan tempat tinggal bagi mereka yang tidak berpunya. Pada tahun 2010, luas tanah koloran itu mencapai 24 hektar. Koloran ini tidak sepatutnya dikuasai oleh elite desa, tetapi harus menjadi kas desa yang bisa dipinjamkan atau disewakan kepada masyarakatnya. Apalagi keberadaan koloran ini telah ditegaskan dengan kekuatan mitologi Dampo Awang yang diyakini masyarakat. Selain itu, tradisi koloran ini pun berkesesuaian dengan orientasi segoro yang dipegang masyarakat nelayan. Selain dapat digunakan untuk tempat tinggal bagi mereka yang tidak berpunya, lembaga tradisi koloran ini bisa dimanfaatkan sebagai alat pengentasan kemiskinan nelayan dengan cara menjadikannya sebagai fasilitas produksi sampingan dari mata pencarian pokoknya. Jatah tanah koloran tersebut dipinjamkan dan digunakan nelayan untuk dibuat tambak udang-udang kecil (udang 
sayur) yang bibitnya berasal dari air laut yang masuk ke tambak. Udang ini dapat dipanen pada 15 hari setelah air laut baru masuk ke tambak, tanpa harus diberi pakan. Rata-rata satu petak tambak seluas $10 \times 10$ meter itu dapat menghasilkan sedikitnya 15 kilogram udang kecil dengan harga Rp. 22.000 per kilonya. Artinya, mereka akan mendapatkan uang setidaknya Rp. 330.000 per setengah bulan atau sekitar Rp. 700.000 per bulan. Uang hasil tambak ini bisa menjadi tabungan bila hasil laut berlebih, dan menjadi pemenuh kebutuhan bila hasil laut sedang sepi.

Kedua, alang-alang, tradisi kedermawanan dalam bentuk pemberian hasil laut untuk orang miskin yang menjadi tetangganya. Tradisi ini telah banyak membantu kehidupan orang miskin, minimalnya pemenuhan kebutuhan pangan. Menumbuhkan tradisi alang-alang tidak dapat diartikan sebagai penyemaian sikap mengemis pada masyarakat nelayan. Tradisi ini ada sebagai wujud kepedulian mereka terhadap tetangganya yang tidak lebih baik nasibnya. Semua orang nelayan di Tunggulsari tahu siapa-siapa saja yang dapat dikriteriakan sebagai penerima alang-alang. Kriteria itu misalnya hanya menjadi pendego, jompo, beranak banyak, tidak punya rumah, yatim atau piatu, orang baik, dan seterusnya. Tradisi ini akan lebih efektif menyentuh orang miskin, bila cara pembagiannya dilakukan secara merata, sehingga tidak bertumpuk pada seorang atau satu keluarga saja. Prosesnya bisa ditetapkan melalui anjuran "bapak angkat" pada musyawarah himpunan keluarga nelayan yang ada di Tunggulsari.

Ketiga, jimpitan, suatu tradisi kutipan hasil tangkapan melalui kesepakatan warga semisal tiga ekor ikan atau tiga ekor udang atau tiga ekor rajungan atau semangkok ikan teri sesuai besaran tangkapan untuk kepentingan dana sosial seperti biaya perawatan rumah sakit, santunan orang jompo dan anak yatim, pembangunan jalan, perbaikan rumah orang miskin, dan sebagainya. Tradisi ini telah menjadi ideal ketika mampu membantu orang miskin dan menjauhkannya dari utang ke bank titil. Jimpitan juga telah dirancang untuk mengurangi buwoh pada kondisi hajatan anggota masyarakat lain. Mekanismenya telah diatur dan disepakati bersama dalam musyawarah kelompok nelayan. Tradisi ini sebenarnya telah berjalan, namun masih kurang efektif karena beberapa orang bakul kadang tidak mau melakukan itu kepada langgannya. Mereka takut dituduh menyalahgunakan hasil jimpitan itu.

Keempat, embungan atau jomblangan, ia tidak sekadar suatu kolam air tadah hujan untuk pemenuhan kebutuhan air bersih masyarakat nelayan. Di dalamnya telah ada aturan-aturan ketat untuk membantu orang miskin dari keterbatasan terhadap air bersih yang umumnya terjadi di wilayah-wilayah nelayan. Tradisi ini pun dijalankan dengan mempertimbangkan kualitas dan kuantitas air yang ada di embungan. Untuk menjaga kualitas air, seluruh nelayan berkewajiban menjaga embungan dari kotoran dan rabat yang melingkupinya. Sementara untuk menjaga kuantitas, ada ketetapan pelarangan penggunaan pompa air atau mesin, baik untuk memenuhi kebutuhan rumah tangga ataupun untuk sawah. Semua orang hanya diperkenankan mengambil air (ngangsu) dengan cara dijinjing, dipikul atau menggunakan sepeda pada pagi, siang, dan sore hari. Semua ketetapan ini harus dilaksanakan masyarakat dengan tujuan agar air di dalam embungan dapat bertahan sampai musim hujan berikutnya. Tujuannya, agar seluruh masyarakat tidak menghabiskan hasil pekerjaannya hanya untuk membeli air.

\section{Revitalisasi Tradisi Reduksi Kemiskinan}

Empat tradisi yang memiliki peran reduksi kemiskinan nelayan di atas secara faktual telah hadir jauh sebelumnya. Namun, karena ia kadang dibiarkan begitu saja atau dijalankan tanpa suatu kepentingan bersama untuk pengentasan kemiskinan, peran itu tidak begitu tampak, khususnya dalam mengatasi penyebab kemiskinan bersifat eksternal dari kondisi masyarakat. Oleh karenanya, pemerintah harus memberikan stimulus dan penyadaran, baik melalui program maupun inisiasi bagi masyarakat untuk dapat 
merevitalisasi secara aktif dan proaktif tradisi yang memiliki peran pengentasan kemiskinan. Dalam proses dampingan itu, karakter kebudayaan masyarakat nelayan beserta ruang endemik wilayahnya harus diperhatikan. Tujuannya memaksimalkan stimulus dan memosisikannya agar tidak bertentangan dengan kebudayaan masyarakat yang bisa saja berakibat fatal bagi masyarakat dan tradisi yang dimilikinya. Di bawah ini ditampilkan satu skema proses stimulus penguatan dan revitalisasi tradisi dan kelembagaan masyarakat nelayan untuk pengentasan kemiskinan (Gambar 1). tradisi-tradisi yang dapat memerosokkan mereka kepada kemiskinan baik jangka pendek ataupun jangka panjang, seperti buwoh dan bank titil. Apa yang dimaksud dengan "penempatan yang baik" adalah satu posisi dan cara masyarakat mengatur dan mengukur kemampuan untuk memenuhi kebutuhannya yang didasarkan pada solidaritas, roso dan keterdesakan atas kebutuhan pokok. Selama masyarakat belum bisa menawarkan dan menyediakan solusi pemberian dana tunai untuk kebutuhan pokok dan kebutuhan roso (buwoh), semisal peminjaman dari dana

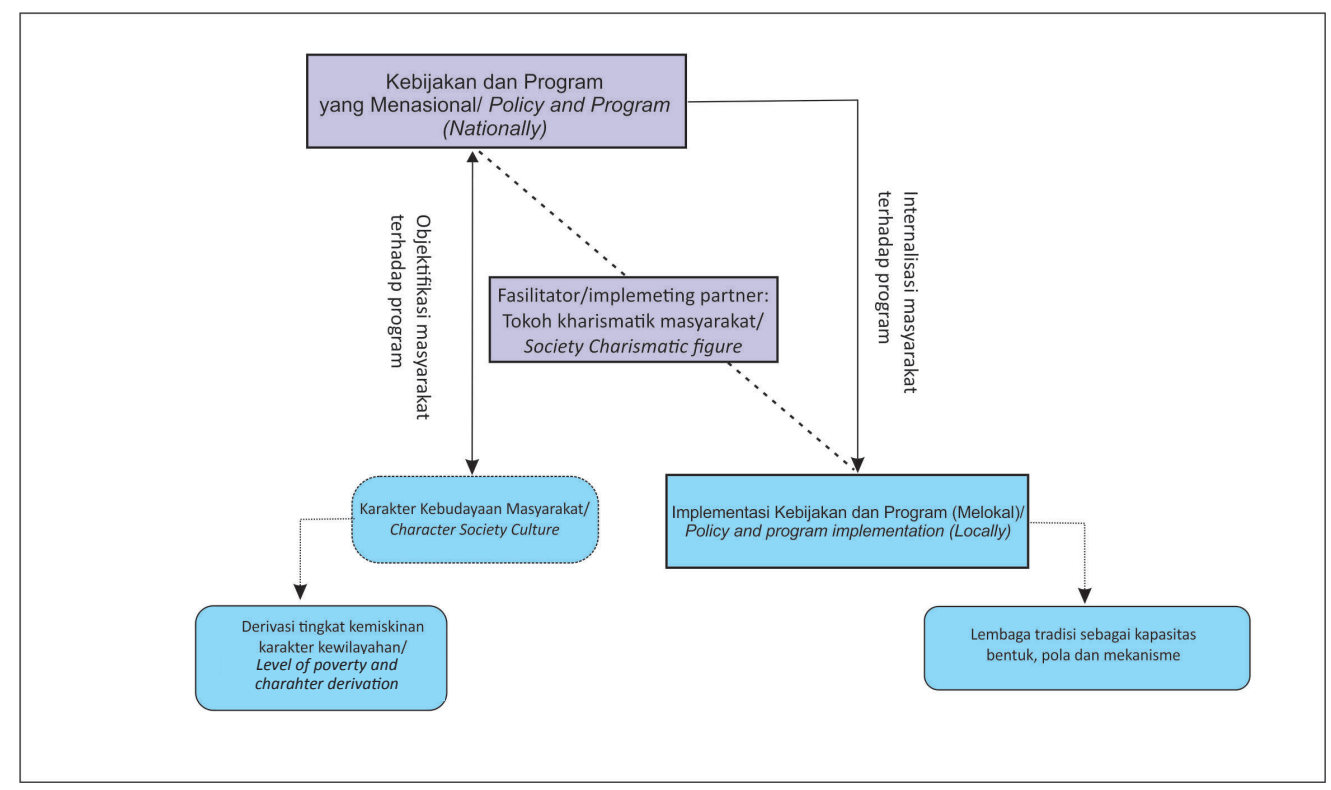

Gambar 1. Skema Alur Revitalisasi Program dan Stimulus Penguatan Tradisi dan Kelembagaan Masyarakat dalam Pengentasan Kemiskinan.

Figure 1. Scheme of Program Revitalization and Tradition Strengthen Stimulus and Society Institutional in Decreasing Poverty.

Bila skema di atas dapat dioperasionalkan dengan baik, harapannya orang atau masyarakat nelayan dapat dientaskan dari kemiskinan, minimalnya dapat terlepas dari penyebab kemiskinan eksternal yang 3 juga akan mampu melepaskan penyebab kemiskinan internal dalam mekanisme produksinya. Mekanisme operasional dari skema di atas juga harus didukung oleh penyadaran dan pendidikan masyarakat tentang "penempatan yang baik" jimpitan, maka mekanisme buwoh dan bank titil tidak dapat dilarang keberadaannya.

\section{KESIMPULAN DAN IMPLIKASI KEBIJAKAN}

Kemiskinan sangat lekat pada kehidupan masyarakat nelayan, tidak hanya di Kaliori Rembang saja, tetapi secara umum telah menjadi "suatu keadaan faktual" di seluruh wilayah Indonesia. Bahkan, bila 
menganalogikannya dengan pendapat James Scott (1994), bahwa petani termasuk nelayan di Asia Tenggara secara umum bersifat subsisten dengan ekonomi moral safety first. Perumpamaannya, orang nelayan "bagai orang yang terendam di air laut sebatas leher, sehingga bila ada sedikit gelombang saja, bisa menenggelamkannya".

Kemiskinan yang disebabkan oleh kondisi internal dalam mekanisme produksi biasanya langsung ditanggapi pemerintah melalui berbagai programnya. Namun tidak demikian dengan penyebab kemiskinan eksternal, seperti buwoh dan bank titil yang muncul bersama dalam kehidupan dan praktik kebudayaan masyarakat sangat jarang ditanggapi sebagai faktor penting kemiskinan faktual. Bisa dikatakan bahwa penyebab kemiskinan eksternal nelayan hadir bersama dengan sistem sosial dan budaya mereka, khususnya perilaku yang berhubungan dengan kewajiban sosial dan produktivitas ekonomi. Banyak nelayan yang menjadikan buwoh sebagai alat simpan atau alat titip investasi yang dimiliki, walaupun dengan cara utang kepada bank titil sekalipun. Cara pandang seperti ini, selain diartikan untuk mengurangi beban kesenjangan dan terhindar dari keterasingan dalam pergaulan sosialnya, juga menjadi alat untuk bereksistensi dan bertahan hidup. Bank titil memanfaatkan cara pandang kewajiban sosial ditengah ketidakberdayaan ekonomi nelayan, termasuk dengan mengatasnamakan usahanya sebagai koperasi. Akibatnya, nelayan terjerat oleh utang bank titil, dan terlepas dari uluran peminjaman bakul yang sering disalahartikan oleh pihak luar sebagai tengkulak.

Namun demikian, hadirnya tradisi dan kelembagaan yang memiskinkan itu, juga biasanya diikuti pula oleh tumbuh kembangnya tradisi yang mampu mereduksi kemiskinan. Sayangnya, tradisi dan kelembagaan tradisi yang berfungsi mereduksi kemiskinan itu kadang didiamkan atau dibiarkan begitu saja oleh masyarakat pelaku dan pemerintah. Oleh karena itu, stimulasi dan dampingan untuk usaha revitalisasi dan penguatan tradisi yang mereduksi kemiskinan dan mencegah pemiskinan di masyarakat nelayan seharusnya menjadi perhatian penting bagi pemerintah dalam merumuskan dan mengimplementasikan kebijakan dan program nasional pengentasan kemiskinan khususnya bagi masyarakat nelayan di Indonesia. Salah satu caranya adalah melakukan "pengelolaan kebudayaan" secara inheren masyarakat dan dampingan pemerintah terhadap tradisi dan kelembagaan tradisi yang dapat mereduksi kemiskinan.

\section{DAFTAR PUSTAKA}

Adhuri, D.S., R. Indrawasih, A. Wahyono, M. Imron, I.G.P. Antariksa, H. Yudomustopo, S. Ali, J. Haba, H. Herman dan Sudiyono. 2004. Pengelolaan Sumber Daya Alam Terpadu (Co-Management). LIPI Press. Jakarta. Hal. 2-7.

Anonim.2002. Tata Kelola Kawasan Bahari Terpadu. Jakarta: DKP. Hal. 7-17. . 2009. Profil Kabupaten Rembang. Rembang. . 2009. Laporan Akhir Kegiatan Prasarana Pembangunan Drainase dan Kegiatan Ekonomi Simpan Pinjam Kelompok Perempuan Tahun 2008. Rembang: PNPM Mandiri. UPK Kaliori. Hal. 3-12.

Dahuri, R. 2004. Keanekaragaman Hayati Laut: Aset Pembangunan Berkelanjutan Indonesia, Gramedia. Jakarta. Hal. 94-110.

Humaedi, M. A. 2010. Jeragan Nemen: Hubungan Ekonomi-Politik Bakul Langgan. Jurnal Masyarakat Indonesia, 2(II):133-163.

Imron, M. 2006. Ko-Manajemen dalam Pengelolaan Sumberdaya Laut: Kasus Kota Tegal. LIPI Press. Jakarta. Hal. 1-4.

2011. Nelayan dan Kemiskinan. Jurnal Masyarakat dan Budaya, Vol. 13, Edisi Khusus, PMB LIPI, Hal. 57-82

---. 2010. Program Pengentasan Kemiskinan (Pronangkis) Kabupaten Rembang. Rembang: Setda dan Bappeda. Hal. 15-28.

Kecamatan Kaliori. 2007. Monografi Desa Kecamatan Kaliori 2006. Kaliori: Sescam. Hal. 11-19. 
Kleden-Probonegoro, Ninuk \& M. Alie Humaedi. 2010. Etnografi Kemiskinan. LIPI Press. Jakarta. Hal. 23-27.

2011. Lembaga Tradisi: Antara Eksistensi dan Reproduksi Kemiskinan. LIPI Press. Jakarta. Hal. 67-90.

Listyaningsih, U. 2004. Dinamika Kemiskinan di Yogyakarta. Pusat Studi Kependudukan dan Kebijkan UGM-Partneship For Economic Growth USAID. Yogyakarta. Hal. 29-38.

Mubyarto, Listianingsih dan H. Nugroho. 1984. Nelayan dan Kemiskinan: Beberapa Kasus Wilayah Nelayan. UGM Press. Yogyakarta:. Hal. 3-6.

Satria, A. 2009. Ekologi Politik Nelayan. LKiS. Yogyakarta. Hal. 24-88.
2003. "Gerbang Mina Bahari" dalam Gatra, No. 52 Tahun IX, 15 November. Hal. 14-16.

Scott, J. C. 1994. Moral Ekonomi Petani. LP3ES. Jakarta. Hal. 33-38.

Semedi, P. 2001. Close to the Stone, Far from the Throne. The Story of a Javanese Fishing Community, 1820s-1990s. Universitiet van Amsterdam. Amsterdam. Hal. 18-27.

Spreadly, J. P. dan D.W. Mc Curdy 1972. The Cultural Experience: Ethnograpy in Complex Society. Chicago: Science and Research Assosiation, inc. Hal. 23-106. 